\title{
THEORETICAL FOUNDATIONS OF TEACHING HYDROPATIC PRESSURE AND ITS PROPERTIES IN HIGHER EDUCATION TECHNICAL SPECIALTIES
}

\author{
Nazarov Odil Omonkulovich
}

Assistant Of The Karshi Engineering Economics Institute, Uzbekistan

\section{ABSTRACT}

In the present, in our lives effective and more efficiently and more than the global changes in the science of the studio, which are operating in the region, in our region, and in the world. It is obvious that the potential to be used. This article contains the theoretical foundations of teaching hydropic pressure and its properties in higher education technical specialties.

KEYWORDS: - Hydrostatic Pressures and its properties, hydraulic, mass with correspondence, main differential equality, liquid balance, and other pressure surfaces, etc.

\section{INTRODUCTION}

From the days of independence of our country, in our country, in all sectors of the economy are taking place in all sectors of the economy. In particular, reforms are being consistently carried out in the field of water. Agromajema network accounting for significant role in the economy of our country We can imagine how much it is necessary for the specialists of the agealing industry in the future.

\section{ReSEARCH METHODOLOGY}

Hydrotechnical structures for which 4.5 million hectares of hectares (water acquisitions, water warehouses, farm channels, interior systems) for many years as a result of many years today The need to reconnounces for re-repairing and reconstruction of these in an efficient, economical opinion - is demanding in the future. Specialists demonstrate this hard or honorable problem. To do this, you need to provide higher education in the field of industry with the literature that meets today's requirements. With this in mind, the authors were able to create literature in the development of hydraulic science in the development of water in the country in our country. Of course, evaluation of the quality and comfort of this textbook Refer to the judging of the students.

AnAlysis AND RESUlts

Hydrostatic pressure and its properties. 
CURRENT RESEARCH JOURNAL OF PEDAGOGICS 2(12): 179-184,

December 2021 DOI: https://doi.org/10.37547/pedagogics-crjp-02-12-35

ISSN 2767-3278

(C)2021 Master Journals

Crossref do: 81 Google

Accepted 26 $6^{\text {th }}$ December, 2021 \& Published 31 ${ }^{\text {th }}$ December, 2021

Hydrostatics is a department of hydropliament and studies the legislation of the liquid. Before consideration of these laws, we view the forces that affect the volume of fluids in peace.

The external forces affecting this size are divided into two groups:

1. Mass (or size) forces. These forces are influenced by the proporial (or non-standard density environment) and all points of this volume environment of the liquid size mass.

2. Extensive forces. These forces affect the outer surfaces of the liquid separated and proportional to the surfaces of these secular. Atmospheric pressure on the free surface of the surface, the atmospheric pressure on the free surface of the liquid, a bowl of the dish wall, a pisten pressure in the liquid, etc. The surface size of the surface is uninterrupted in the surface of the separated liquid. In every point of the liquid fluid fluid, the inner forces will occur in the influence of liquid voltage under the influence of external forces. The voltage position at each point of fluid is characterized by pressure.

We look at the optional volume of liquid that is in balance at the influence of external forces (Figure 1). We assume that we cut out this volume by some plane and throw out the part that is located on one side of this plane. To maintain its equilibrium state, we replace the remaining part with some $\mathrm{P}$ Equal acting force. If in the cutting plane, is allocated to the elementary surface, then is affected by a part of the force of equal magnitude. relative limit of in zero reduction of the surface is called the ppphostatic pressure at the point of view of the liquid:

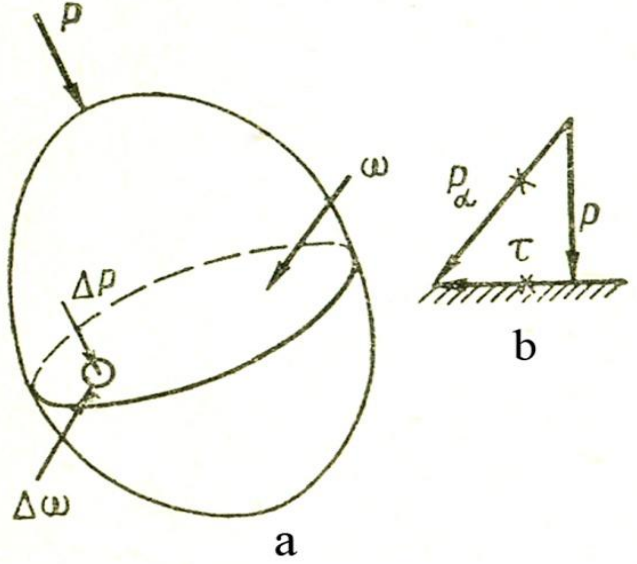

$$
p=\lim _{\Delta \omega \rightarrow 0} \frac{\Delta P}{\Delta \omega}
$$

Or

$$
p=\frac{d P}{d \omega}
$$
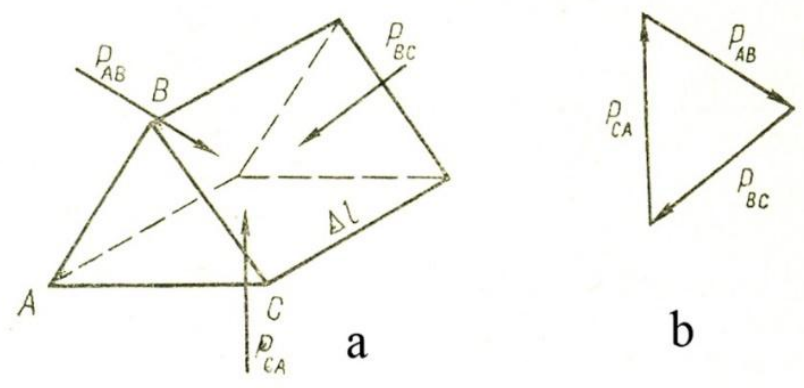

b 
CURRENT RESEARCH JOURNAL OF PEDAGOGICS 2(12): 179-184,

December 2021 DOI: https://doi.org/10.37547/pedagogics-crjp-02-12-35

ISSN 2767-3278

(C)2021 Master Journals

Crossref do: 81 Google

Accepted 26 th December, 2021 \& Published 31 ${ }^{\text {th }}$ December, 2021

Idrostatic pressure is characterized by three main properties:

1.Chydrostatic pressure forms normal oriented to plain and only compressible voltages. Indeed, the liquid will not form elongated tension. If the liquid is in peace, then then there are no urine voltages. The pressure cannot influence the angle that is different from . If you had influenced it, it would be spread to normal and attempts (Fig. 2). But attempts only occur in the liquid movement. Therefore, as a result, the pressure forms normal and compressive voltages only.

2. The gostatic pressure is the same in all directions of the optional point of the liquid. To prove this property,we distinguish the prism in the form of a triangle from the bases ABC (Figure 2 , A) of the volume of the liquid that is considered, and replace the sides of the liquid that are not in the prism with the corresponding forces that affect the volume of the liquid. So the prism will be in balance, in which the multiple angles of these forces (triangle if viewed) will be closed. Forces triangle $\mathrm{ABC}$ is a triangle by analogy and by analogy

$$
\frac{P_{A B}}{A B}=\frac{P_{B C}}{B C}=\frac{P_{C A}}{C A}
$$

will be.

$$
1 \mathrm{kgs} / \mathrm{sm}^{2}=98100 \mathrm{H} / \mathrm{m}^{2}=98100 \mathrm{~Pa}=98,1 \mathrm{kPa}=0,098,1 \mathrm{MPa} \approx 0,1 \mathrm{MPa}
$$

given.

Defferential equations of fluid equilibrium (Eyler's equation) and their integration. In the liquid that is in equilibrium, we distinguish an infinite small volume in the form of a parallelepiped with edges $d x, d y$ and $d z$ (Figure 3). We throw out the
$\mathrm{Bu}$ tenglikning hamma a'zolarini prizma uzunligiga bo'lamiz:

$$
\frac{P_{A B}}{A B \cdot \Delta \lambda}=\frac{P_{B C}}{B C \cdot \Delta \lambda}=\frac{P_{C \cdot A}}{C A \cdot \Delta \lambda}
$$

will be.

$\mathrm{Bu}$ tenglikning hamma a'zolarini prizma uzunligiga bo'lamiz:

$$
P_{A B}=P_{B C}=P_{C A}
$$

we form.

Since the orientation of the sides of the prism is obtained voluntarily, it can be assumed that the rule on the equality of pressure in all directions of one point is proved.

3. The gostatic pressure in the point depends only on its location in space, that is

In the SI system of units, the pressure is measured in Pascal $(\mathrm{Pa})$, kilopascal $(\mathrm{kPa})$ and megapascal $(\mathrm{mPa})$. In many technical literature, the pressure measurement is used in technical atmospheres $\left(k g s / s m^{2}\right)$. 
CURRENT RESEARCH JOURNAL OF PEDAGOGICS 2(12): 179-184,

December 2021 DOI: https://doi.org/10.37547/pedagogics-crjp-02-12-35

ISSN 2767-3278

(C)2021 Master Journals

Crossref do: 81 Google

Accepted 26 $6^{\text {th }}$ December, 2021 \& Published 31 ${ }^{\text {th }}$ December, 2021

of the right side, where the coordinates are $x+d x, y, z$. Let's assume that with the growth of $x$ coordinates on the $x$ axis, the pressure also increases. Since the $A$ and $A_{1}$ coordinates of $z$ and $y$ points are the same, then at the $A_{1}$ point

$$
p+\frac{\partial p}{\partial x} d x
$$

All over the left side

the force of pressure, while on the right

$$
-\left(p+\frac{\partial p}{\partial x} d x\right) d y d z
$$

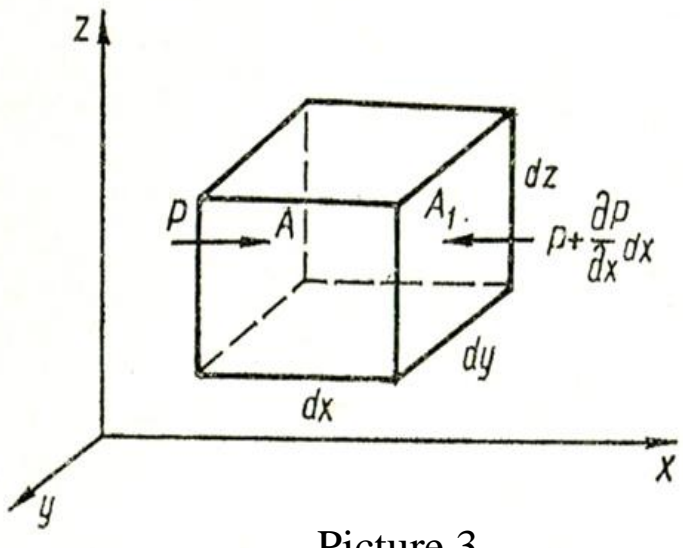

Picture 3

the forces of pressure are affected. A negative sign indicates that the force affects the opposite side in the direction of the arrow. Paralellopiped is influenced by the forces of compression by the external fluid.

In addition to the forces acting on the parallellopiped, where the projection of the $\mathrm{x}$ axis is , the pressure can also be affected by mass forces (for example, the force of gravity, centrifugal inertia or some mixed forces).

On the axis of view, this is the sum of the projections of all forces

$$
p d y d z-\left(p+\frac{\partial \mathrm{P}}{\partial x} d x\right) d y d z+\rho d x d y d z=0
$$

or from simplification key $X-\frac{1}{\rho} \cdot \frac{\partial p}{\partial x}=0$ will be.

In the same way, we form equations for $\mathrm{Y}$ and $\mathrm{Z}$ arrows:

$$
\left.\begin{array}{r}
X-\frac{1}{\rho} \frac{\partial p}{\partial x}=0 \\
Y-\frac{1}{\rho} \frac{\partial p}{\partial y}=0 \\
Z-\frac{1}{\rho} \frac{\partial p}{\partial z}=0
\end{array}\right\}
$$

These equations are considered to be the asosoy differential (Eyler's equation) equation of the equilibrium of the liquid. Each equation expresses a change in pressure when one of the coordinates changes.

In the case of several coordinate changes, it is necessary to establish the laws of pressure change uvhun, to look at the Eyler equation that corresponds to the coordinate axes together. By multiplying Equation $\rho d x, \mathbf{2}$ by $\rho d y \mathbf{3}$ by $\rho d z$ , and adding the terms,

$$
\frac{\partial p}{\partial x} d x+\frac{\partial p}{\partial y} d y+\frac{\partial p}{d z} d z=\rho(X d x+Y d y+Z d z)
$$

\section{(7)}

we form the equation.

The left-hand side of this equation represents the full pressure differential : 
CURRENT RESEARCH JOURNAL OF PEDAGOGICS 2(12): 179-184,

December 2021 DOI: https://doi.org/10.37547/pedagogics-crjp-02-12-35

ISSN 2767-3278

(C)2021 Master Journals

Crossref do) 81 Google

Accepted $26^{\text {th }}$ December, 2021 \& Published $31^{\text {th }}$ December, 2021

$d p=\rho(X d x+Y d y+Z d z)$

Equation (8) is called the basic differential equation of hydrostatics. The special parentheses on the right side of this equation

$$
\frac{\partial F}{\partial x}=X ; \quad \frac{\partial F}{\partial \gamma}=Y ; \quad \frac{\partial F}{\partial z}=Z
$$

$\left(\mathbf{8}^{1}\right)$

can be expressed in the form of a complete differential of any potential function $\mathrm{F}$ equal to. It follows that the field of mass forces is potential. Then equation (1.81)

$$
d p=\rho d F
$$

or

$$
d p=-\rho d E_{p}
$$

here $-d E_{p}=d F \cdot E_{p}(x, y, z)$ the function represents the potential energy of the field of mass forces.

Incompressible fluid ( $\rho=$ const $)$ by integrating (1.9),

$p=-\rho E_{p}+C$ or $p+\rho E_{p}=C$

expressions.

Equal pressure surfaces. When the pressure is the same at all points on the surface, such surfaces are called equal pressure surfaces.

In Equation (8) we form the differential equation of a group of surfaces of equal pressure as $\rho \neq 0$ in $d p=0$ :

$$
X d x+Y d y+Z d z=0
$$

Or

$$
E_{p}(x, y, z)=\text { const }
$$

Different variations in (11) will be suitable for different pressure surfaces. The freedom of fluid is also one of the equal pressure surfaces limited to the gas environment.

In the balance of fluids, the mass power at any point of the liquid is directed to the normal, the equal pressure surfact that crosses the point.

\section{Conclusions}

Thus, as the development of science is now, as an object in hydraulic, it is accepted not only water, but also the fluids present in all nature. It is not possible for future physicians with the hydraulic science of physiology. The evidence of our opinion can be used by the model of artificial human university, created by scientists of the Department of Hydraulics, is widely used by the model of artificial values.

Since hydraulic laws are used in all areas of technology, the practical significance of this subject is excellent. Areas of use of hydraulic proficiency - hydraulic engineering, water reclamation, hydropic water supply and sewerage, machinery, aviation, etc.

\section{REFERENCES}

1. Bozorov D.R., Karimov R.M. Gidravlika asoslari. T. 2004.

2. Гиргидов А.Д. Механика жидкости и газа (Гидравлика). Учебник. СанктПетербург. Издателство СПбГПУ. 2004.

3. Karimov A.A., Shokirov A.A., Mukolyans A.A. "Gidravlika asoslari, nasoslar va kompressorlar”, O'quv qollanma, Noshir, $\mathrm{T}: 2013$.

4. Кристеа Н. Подземная гидравлика. Том 2. М.: Гостоптехиздат. 1962. 
CURRENT RESEARCH JOURNAL OF PEDAGOGICS 2(12): 179-184,

December 2021 DOI: https://doi.org/10.37547/pedagogics-crjp-02-12-35

ISSN 2767-3278

(C)2021 Master Journals

Crossref doi) 81 Google

Accepted 26 th December, 2021 \& Published 31 th December, 2021

5. Пыхачев Г.Б., Исаев Р.Г. Подземная гидравлика. М.: Недра. 1973. 360 с.

6. Сиддиқхўжаев Р.К., Акрамов Б.Ш. Нефть ва газ қатлами физикаси. Тошкент. КМТАФ, 1994. 204 б.

7. Чарный И.А. Подземная гидрогазодинамика.М.: Гостоптехиздат.1963.

8. Шелькачев В.Н., Лапук Б.Б. Подземная гидравлика. Москва-Ижевск. 2002. 735 с.

9. Vaclav Halek, Jan Svec. Groundwater hydraulics. Elsevier scientific publishing company. Amsterdam - Oxford - New York - 1979. -621 p

10. Kuniaki Sato, Yoshiaki Iwasa (Eds.) Groundwater Hydraulics. Originally published by Springer-Verlag Tokyo Berlin Heidelberg New York in 2000. -210p. 